\title{
Hydrogeological flow in gypsum karst areas: some examples from northern Italy and main circulation models
}

\author{
Bartolomeo Vigna ${ }^{1}$, Ilenia M. D’Angeli², Adriano Fiorucci ${ }^{1}$, and Jo De Waele ${ }^{2 *}$ \\ ${ }^{1}$ Department of Territorial Engineering, Environment and of Geotechnologies, Politechnical University of Turin, \\ Corso Duca degli Abruzzi 24, 10129 Torino, Italy \\ ${ }^{2}$ Department of Biological, Geological and Environmental Sciences, University of Bologna, Via Zamboni 67, 40126 Bologna, Italy
}

\begin{abstract}
A Messinian succession containing gypsum beds crops out in northern Italy, mainly in Piedmont and along the northern flank of the Apennine mountains in Emilia-Romagna. These gypsum bodies have been extensively quarried at the surface, in outcrops, and through underground quarries. In Emilia-Romagna these gypsum outcrops can be rather extensive, several $\mathrm{km}$ long and up to $1 \mathrm{~km}$ wide, while in Piedmont they are mostly covered by silty-marly deposits of Upper Messinian and Pliocene age and show only sparse and small outcrops. The underground quarrying of these evaporite bodies in Piedmont has allowed studying in detail their hydrogeology, and the ways in which water flows through these karst rocks. In contrast, in Emilia-Romagna the hydrogeology of these aquifers has been studied with traditional spring water monitoring and speleological methods. On the basis of the results it has been possible to define three conceptual models regarding the water circulation in these evaporites, similar to the models existing for carbonate aquifers. The models represent aquifers with decreasing vulnerability to pollution, from the more vulnerable system with dominant conduit drainage, characterizing most of the known gypsum aquifers, to those with interconnected conduit drainage and with dispersive circulation.
\end{abstract}

Keywords: $\quad$ karst hydrogeology, evaporites, flow models, gypsum caves, vulnerability to pollution Received 24 November 2016; Revised 16 May 2017; Accepted 17 May 2017

Citation: Vigna B., D’Angeli I.M., Fiorucci A. and De Waele J., 2017. Hydrogeological flow in gypsum karst areas: some examples from northern Italy and main circulation models. International Journal of Speleology, 46 (2), 205-217. Tampa, FL (USA) ISSN 0392-6672 https://doi.org/10.5038/1827-806X.46.2.2095

\section{INTRODUCTION}

Although largely underexploited, karst aquifer systems often deliver large amounts of high-quality drinkable water and already serve about a quarter of the world's population (Ford \& Williams, 2007). These aquifers are hosted in limestones and dolostones, and because of their increasing strategical role in local, regional and national development plans, they have often been intensively studied, especially the Mediterranean area, where domestic water supply can be ensured by these aquifers (Bakalowicz, 2015). Gypsum karst aquifers have been studied far less than carbonate ones, because their waters are normally undrinkable. However, in some regions, these aquifers represent the only available water resource, and therefore they have been studied from a hydrogeological and geochemical point of view. More often, gypsum karst springs have been studied in detail because they interfere with fresh water bodies, such as rivers, deteriorating the water quality of these surface resources. This is the case of Sivas (Turkey)
(Günay, 2002), where the two main springs of the area (Göydün and Seyfe springs), being rich in salt and gypsum, decrease the water quality of the Kizilirmak River making it undrinkable for the Sivas city located downstream (Kaçaroğlu et al., 2001). Gypsum karst aquifers are also regularly studied in Iran, in connection with large projects of dam construction (Aghdam et al., 2012). Iran is one of those countries where gypsum rocks cover large areas, reaching almost $5 \%$ of the entire land surface of this country (Raeisi et al., 2013). Aghdam et al. (2012) report the progressive salinization of the Karun River, which crosses gypsum-anhydrite and halite beds of the Gachsaran Formation over a length of $4 \mathrm{~km}$. Gypsum aquifers have also been studied from a geochemical point of view in the semi-arid South of Spain, mainly in the Betic Cordillera (Calaforra et al., 2002), for example in the Salinas-Fuente Camacho area close to Granada (Calaforra \& Pulido-Bosch, 1993, 1999), in the Triassic Antequera diapir close to Malaga (the salty Meliones spring reaching conductivity values as high as 200,000 $\mu \mathrm{S} / \mathrm{cm}$ ) (Benavente \& Carrasco, 1986; 
Andreo et al., 2016), at the Viñicas and Los Molinos springs flowing out of the Sorbas karst (Pulido-Bosch \& Calaforra, 1993), and in the areas where wetlands are caused by regional groundwater flow in which evaporite rocks play a dominant role (e.g., Antequera, Jarales and Brujuelo areas, Gil-Márquez et al., 2017). In most of these case studies the hydrodynamics of flow have been investigated only partially.

Gypsum crops out in almost all Italian regions, but the most significant evaporite karst areas are located in Piedmont, Emilia-Romagna, Marche, Tuscany, Calabria, and Sicily (Madonia \& Forti, 2003; De Waele et al., 2017). Gypsum caves are often of the throughflow type, with a blind valley (sinking stream) and a downstream spring. There are several long gypsum cave-systems; the longest one is Aquafredda-Spipola near Bologna, Emilia-Romagna (Lucci \& Rossi, 2011) reaching a development of over $10 \mathrm{~km}$. Because of the gradual uplift of the Apennines some systems are still-active multi-level caves, formed over the last 500 ka (Columbu et al., 2015, 2017).

The hydrogeology of these Italian evaporite aquifers has been studied only in two regions: Emilia-Romagna and Piedmont (Fig. 1).

In Emilia-Romagna region the gypsum beds are generally exposed, forming prominent large outcrops of monoclinal evaporite ridges surrounded by less permeable and easily erodible lithologies. These gypsum groundwater circulation systems have been investigated in the past including dye tests, geostructural and speleological studies, and some water analysis (Casali, 1972; Forti et al., 1985, 1989; Forti \& Francavilla, 1990). These studies were carried out in areas where the most important caves are known, such as Acquafredda-Spipola system near Bologna and Rio Stella-Basino south of Faenza. Also the major karst outlet of the region, the brackish Poiano springs ( $6 \mathrm{~g} / \mathrm{L} \mathrm{NaCl}$ ) and the nearby Tanone cave, have been studied in detail (Forti et al., 1988; Chiesi \& Forti, 2009). The multiparametric monitoring of Poiano has evidenced the salt concentration to vary in time suggesting a slow uplift of the area, causing the underground circulation to progressively dissolve salty lenses (Chiesi et al., 2010). Finally, in

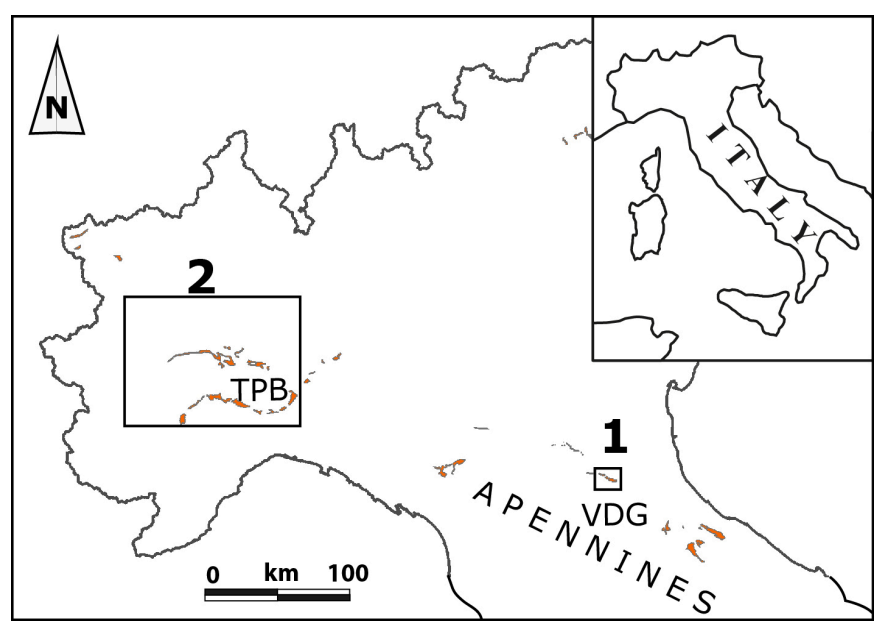

Fig. 1. North Italian gypsum outcrops. TPB = Tertiary Piedmont Basin; VDG = Vena del Gesso Romagnola. 1) Rio Stella-Basino cave system (see Fig. 4 for detail); 2) Tertiary Piedmont Basin with the Moncalvo and Calliano aquifers (see Fig. 7 for detail). the period 2010-2014, a detailed geochemical and microbiological quality assessment of the waters in the Emilia-Romagna gypsum areas was carried out in the framework of the European Project "LIFE + 08NAT/IT/000369 Gypsum" (Bergianti et al., 2013; D’Angeli et al., 2017).

In contrast to Emilia-Romagna, in Piedmont region, gypsum crops out only sparsely, and these rocks are often covered by a thick sequence of sandy-marly and clayey sediments of Upper Messinian-Pliocene age (Dela Pierre et al., 2007). The gypsum succession is quarried underground, with a series of extensive tunnels cutting the evaporite rocks. This favorable situation has allowed obtaining a set of interesting data regarding the underground water circulation.

The results of this monitoring of different gypsum aquifers has allowed to define three conceptual models regarding the water circulation in these evaporites, similar to the models existing for carbonate aquifers. For the purpose of this paper we report the data of three different gypsum aquifers, chosen as the most representative ones of the three hydrogeological models discussed later. One of these is located in the Vena del Gesso Romagnola area (Rio Stella-Basino cave system), while the other two (Moncalvo and Calliano) are hosted in the Tertiary Piedmont Basin (see Fig. 1).

\section{STUDY AREAS}

\section{Geological outline}

The Messinian evaporite sequence in EmiliaRomagna region crops out on northern front of the Apennine Mountains, in a restricted belt striking more or less parallel, to the mountain chain (WNW-ESE). Gypsum beds are rarely horizontal, and often form cuestas in the landscapes, with strata dipping steeply toward the NNE. The gypsum sequence belongs to the Gessoso-Solfifera Formation and is normally underlain by marly or clayey, shaly, poorly permeable sediments of Miocene age (Marnoso-Arenacea Fm.) containing channelized sandy bodies in its lower part and euxinic shales towards its top. The evaporite sequence starts with a limestone bed, and is then characterized by thick primary gypsum beds in its lower part, divided by marly interbeds, whereas towards the top the evaporite beds tend to decrease in thickness and the marly interbeds to increase. Finally, the last gypsum beds are overlain by marly sediments of the Colombacci Fm. and, following, by clays of the Argille Azzurre Fm., both of low permeability (Vai \& Martini, 2001) (Fig. 2A). The complete evaporite sequence is characterized by 16 evaporite cycles, visible only in the eastern part of Emilia-Romagna, in the well-known "Vena del Gesso Romagnola” area (Vai \& Ricci Lucchi, 1977). Whereas in western Emilia-Romagna region, West of the Santerno valley, the evaporite sequence has been subjected to a northward displacement, and is thus detached from its original basement, in eastern Emilia-Romagna the gypsum sediments are in their original stratigraphic position. As a consequence, in western Emilia-Romagna the gypsum outcrops are more fragmented, and show intense deformation, 


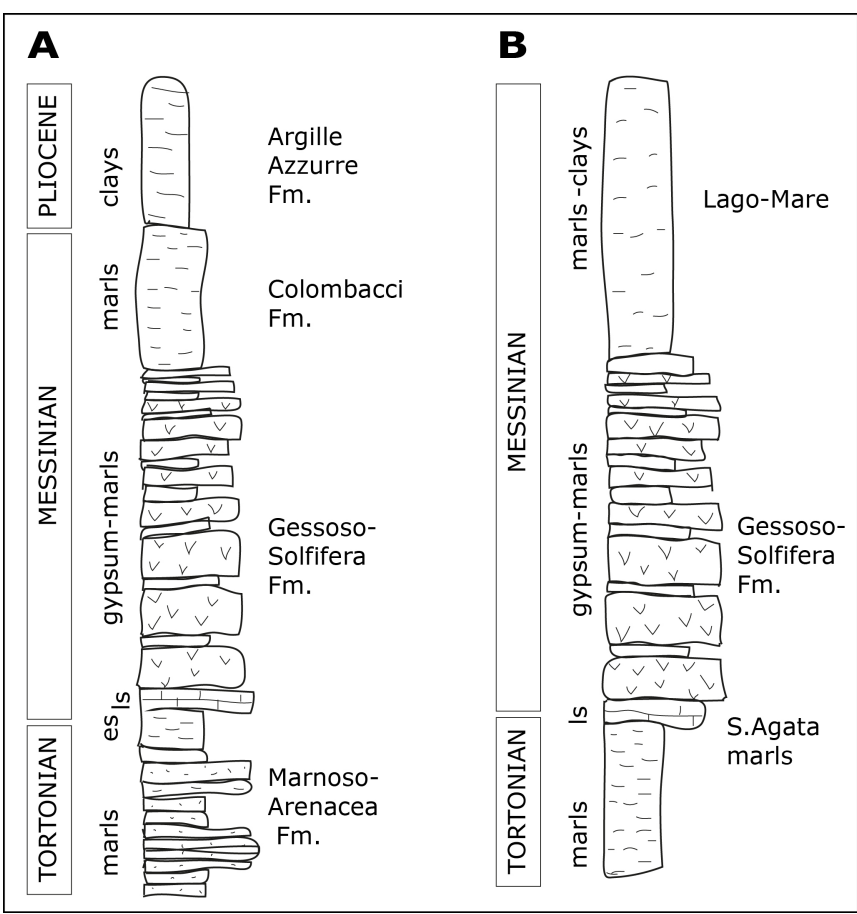

Fig. 2. Schematic stratigraphic columns of the evaporite sequences in A) Emilia-Romagna region, and B) Tertiary Piedmont Basin. Note these stratigraphic columns are generalized and not to scale.

while in eastern Emilia-Romagna the outcrops are more continuous and a little bit less disturbed.

In the central (Monferrato and Turin hills) and southern part (Langhe) of Piedmont, an over $5 \mathrm{~km}$ thick Upper Eocene-Pliocene sedimentary sequence, mainly composed of terrigenous sediments is known in literature as Tertiary Piedmont Basin (TPB). The Messinian succession in this sequence can be found at the surface along two W-E striking belts, and is deeply buried below Pliocene-Quaternary deposits in the Savigliano and Alessandria basins, and can be divided in three main horizons. The lower part is mainly composed of clays (pre-evaporitic phase) and formed under normal to moderately salty conditions. These clays are covered by true evaporites with a cyclic repetition of marl and gypsum beds deposited in a hypersaline lagoon environment (evaporitic or synevaporitic phase, Primary Lower Gypsum). These evaporites are, in turn, covered with a succession of salty-lagoon, deltaic and palustral sediments (post-evaporitic phase) (Sturani, 1976; Dela Pierre et al., 2011).

In the Monferrato area the Messinian deposits are characterized by different facies, composed of evaporite blocks of various dimensions embedded in a fine matrix, resulting from submarine mass wasting processes involving the primary shallow water gypsum beds (Chaotic Complex of Valle Versa) (Ghibaudo et al., 1985; Dela Pierre et al., 2002, 2007). Close to Moncalvo and Calliano (North of Asti), in contrast, the Primary Lower Gypsum beds are still in place (Vigna et al., 2010a, $2010 b)$. The marls at the base of the gypsum beds, known as Sant'Agata Marls, contain some decimeter thick carbonate-rich beds (Dela Pierre et al., 2012). At Moncalvo and Calliano this half-meter thick limestone is covered directly by the evaporites, composed of 10-12 m thick beds of gypsum separated by finely layered dark grey and fossiliferous marly-clays up to 1 meter thick (Fig. 2B). The fourth bed is characterized by $10-15 \mathrm{~m}$ of microcrystalline gypsum, followed by ten more metric to decimetric gypsum levels of progressively decreasing thickness. The marly-clayey interbeds, separating the evaporite cycles, are always dark and laminated and increase in thickness (up to several meters) going upward in the sequence. The total thickness of the eleven microcrystalline gypsum beds reaches $65-70 \mathrm{~m}$. An erosional surface cuts the evaporite sequence causing relevant lateral variations in the quantity of preserved gypsum beds (between 20 and $70 \mathrm{~m}$ thick). The erosional surface is followed by brown-yellowish clay-to-silt deposits sedimented in hyposaline conditions, probably corresponding to the "Lago-Mare" event.

\section{General hydrogeology}

The extensive gypsum areas in Emilia-Romagna often form the highest parts in the landscape, being more resistant to erosion than the adjacent fine-grained sediments (Fig. 3A). The gypsum sequence is mostly exposed, with inclined beds and important WNW-ESE and NNE-SSW faults. These gypsum ridges generally host important karst aquifers, mainly localized along a series of well-developed vadose galleries and cave systems, with poorly extended or almost complete absence of a saturated zone. The water transfer takes place very rapidly along underground rivers and is strictly controlled by rainfall events (Tedeschi et al., 2015). Flow rates vary by orders of magnitude, typical of a well-karstified aquifer. The recharge of these systems is both autogenic (direct infiltration into the gypsum rocks through numerous dolines) and allogenic, through sinking rivers flowing from adjacent low permeability terrains. Geochemical

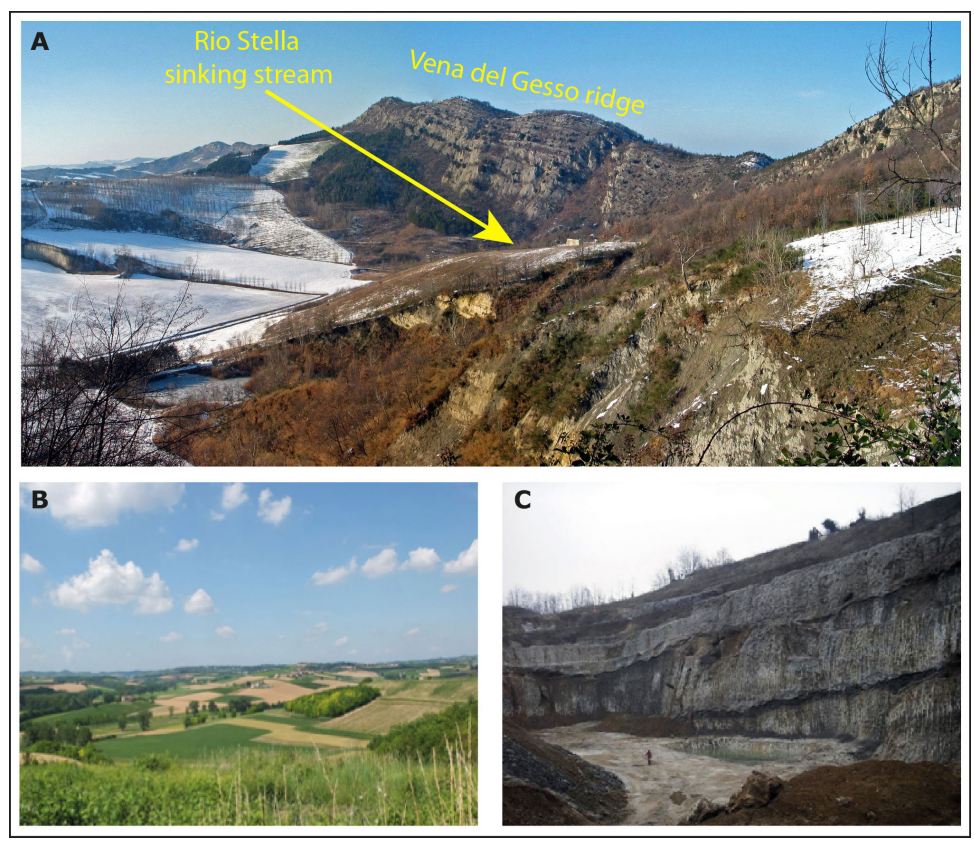

Fig. 3. The studied gypsum areas: A) Vena del Gesso Romagnola ridge with the blind valley of Rio Stella, disappearing underground at the base of the inclined gypsum sequence; B) The hilly landscape around Monferrato mostly carved in the Post-evaporitic sediments of Messinian age; C) The main macrocrystalline gypsum beds exposed at the surface in the open pit quarry at Moncalvo. 
analysis of infiltrating and spring waters, together with multiparametric monitoring of some of the most important springs has allowed characterization of these aquifers from a hydrogeological point of view (Bergianti et al., 2013; Tedeschi et al., 2015; D’Angeli et al., 2017).

The gypsum aquifers in Piedmont region, on the contrary, are sandwiched between sediments with low to very low permeabilities. The waters flowing in these evaporite aquifers derive from slow recharge from the upper and lower aquitards. These gypsum aquifers are, thus, generally characterized by the presence of an extensive saturated zone, along a karstic network that is heavily influenced by the fractures in the host rock.

In the area of Moncalvo and Calliano the surface topography is characterized by a series of gentle hills mostly carved into the post-evaporitic sediments (marls and clays) (Fig. 3B). The evaporite beds are inclined $10-20^{\circ}$, and are mostly buried underneath the Late Miocene-Pliocene sediments (Fig. 3C). The underground quarries in this gypsum follow the overall geometry of these evaporite bodies, and intersect different aquifer levels. A series of boreholes with piezometers, together with kilometers of quarry galleries excavated in the gypsum have allowed reconstructing the hydrogeological structure of this area with great accuracy.

\section{METHODOLOGY}

Gypsum aquifers were monitored using DL/N70 STS multiparameter loggers (electric conductivity, temperature, and water level). All parameters are measured every 60 minutes: pressure sensors have an accuracy of $<0.25$ bar, and a resolution of $\leq 0.01 \% \mathrm{FS}$; Temperature $0.1^{\circ} \mathrm{C}$, precision $+/-0.25^{\circ} \mathrm{C}$, electrical conductivity $1 \mu \mathrm{S} / \mathrm{cm}$ accuracy and a resolution of $\pm 2 \%$ of the measured value. Most piezometers have been equipped with a water pressure logger of the same characteristics as the multiparameter loggers mentioned above.

In a couple of springs flow rates have been measured by triangular weirs coupled with automatic and manual water level measurements. The water level lowering at Calliano has been monitored in boreholes since 2010 by manual measurements carried out every month or so.

Waters have been analyzed for their chemical content in different hydrodynamic conditions. Two samples were collected at each site, $250 \mathrm{ml}$ of normal water and 100 $\mathrm{ml}$ of water filtered with a $0.45 \mu \mathrm{m}$ sterile filter (sterile cellulose acetate, Minisart(C) and acidified with $1 \mathrm{ml}$ of concentrated $65 \% \mathrm{HNO}_{3} . \mathrm{Na}^{+}, \mathrm{K}^{+}, \mathrm{Mg}^{2+}$, and $\mathrm{Ca}^{2+}$ were analyzed with an Atomic Absorption Spectrophotometer Thermo S (AAS). $\mathrm{SO}_{4}{ }^{2-}$, $\mathrm{Cl}^{-}, \mathrm{F}^{-}, \mathrm{Br}^{-}, \mathrm{PO}_{4}{ }^{3-}, \mathrm{NO}_{2}^{-}$, and $\mathrm{NO}_{3}^{-}$were analyzed with Ionic Chromatography (Metrohm 881 bIC Pro), $\mathrm{NH}_{4}{ }^{+}$by Colorimetry (spectrophotometer Hack DR 2010), alcalinity $\left(\mathrm{HCO}_{3}^{-}\right)$through a titration with $\mathrm{HCl}$ and methylorange as indicator.

These studies have allowed characterizing these aquifers from a hydrogeological and geochemical point of view. The acquired data on the different karst systems in Piedmont and Emilia-Romagna regions enabled the definition of three conceptual models of groundwater circulation in gypsum rocks, similar to the classification of carbonate aquifers (Vigna \& Banzato, 2015), which is presented in this paper.

\section{RESULTS AND DISCUSSION}

\section{The Rio Stella-Basino aquifer}

One of the most typical through-flow systems in the gypsum areas of Emilia-Romagna is the Rio StellaBasino cave system (Vena del Gesso Romagnola), composed of a sink (Rio Stella), a completely transitable underground stream passage with some underground tributaries, and a spring (Rio Basino) (Fig. 4) (Forti \& Lucci, 2010). This spring has been monitored, from a hydrogeological point of view, for one year and a half, while water samples at the spring and at the sink were collected for five years. The behavior of this system to infiltration events is typical of all the analyzed gypsum cave systems in this region.

The chemical parameters change quite rapidly in response to the main infiltration events (rainfall), showing a substitution of the resident waters by neoinfiltrating ones (Fig. 5). Water chemistry shows an increase in salinity (Total Dissolved Solids) from the sink to the spring (Fig. 6A-B-C), but also less mineralized waters during rainier periods, well shown in the magenta line (conductivity in Fig. 5). During spring rain periods we observed a decrease in water temperature and conductivity and a respective increase of pressure. In February 2012 it is possible to observe a concurrent drop of water temperature and conductivity in a period in which no rainfall is recorded. This event was caused by snow melting

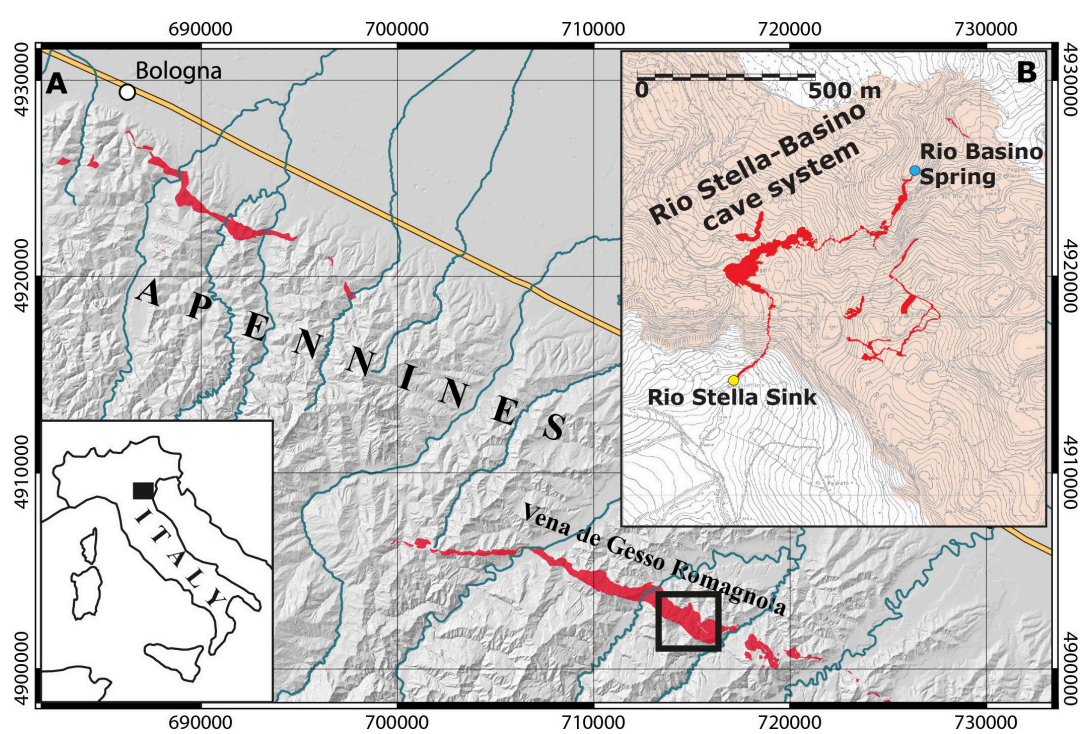

Fig. 4. A) Northern Apennines Messinian gypsum outcrops (in red) showing the location of the Rio Stella-Basino cave system in the "Vena del Gesso Romagnola" (black square); B) Detail of the Rio Stella-Basino cave system in plan view (red areas are the known underground cave passages). The pink shaded area represents the outcropping Messinian gypsum rocks. The yellow dot represents Rio Stella sinking stream, while the blue one is the Rio Basino spring. 


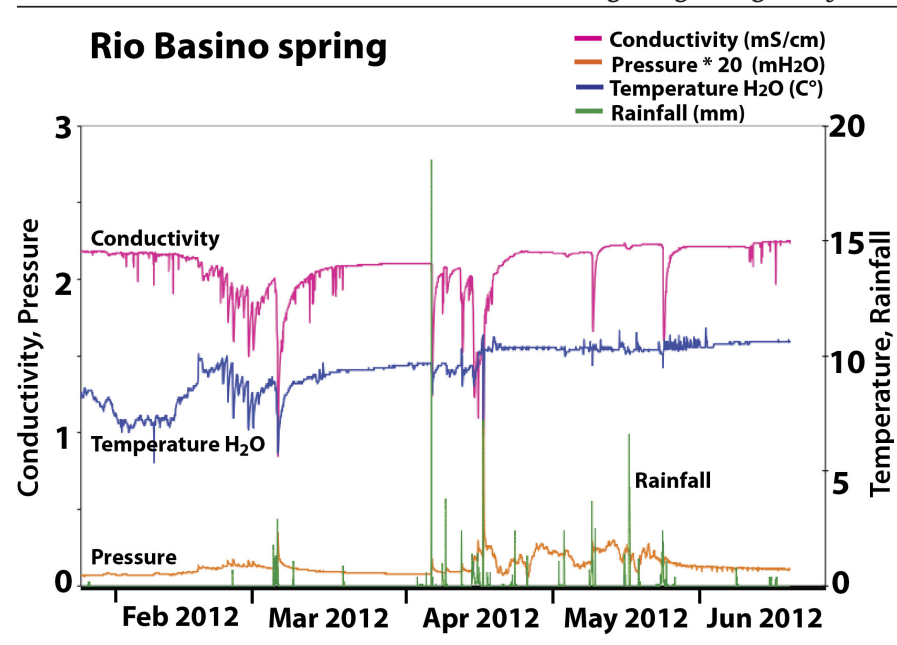

Fig. 5. Rainfall $(\mathrm{mm})$ represented with the green bars, water Temperature $\left(\mathrm{C}^{\circ}\right)$ in blue, pressure $\left(\mathrm{mH}_{2} \mathrm{O}\right)$ in orange and Electric Conductivity $(\mathrm{mS} / \mathrm{cm})$ in magenta color at the Rio Basino spring during winter-spring 2012.

From the graph we observed a decrease in temperature and conductivity subsequently to rainfall events during this period.

A
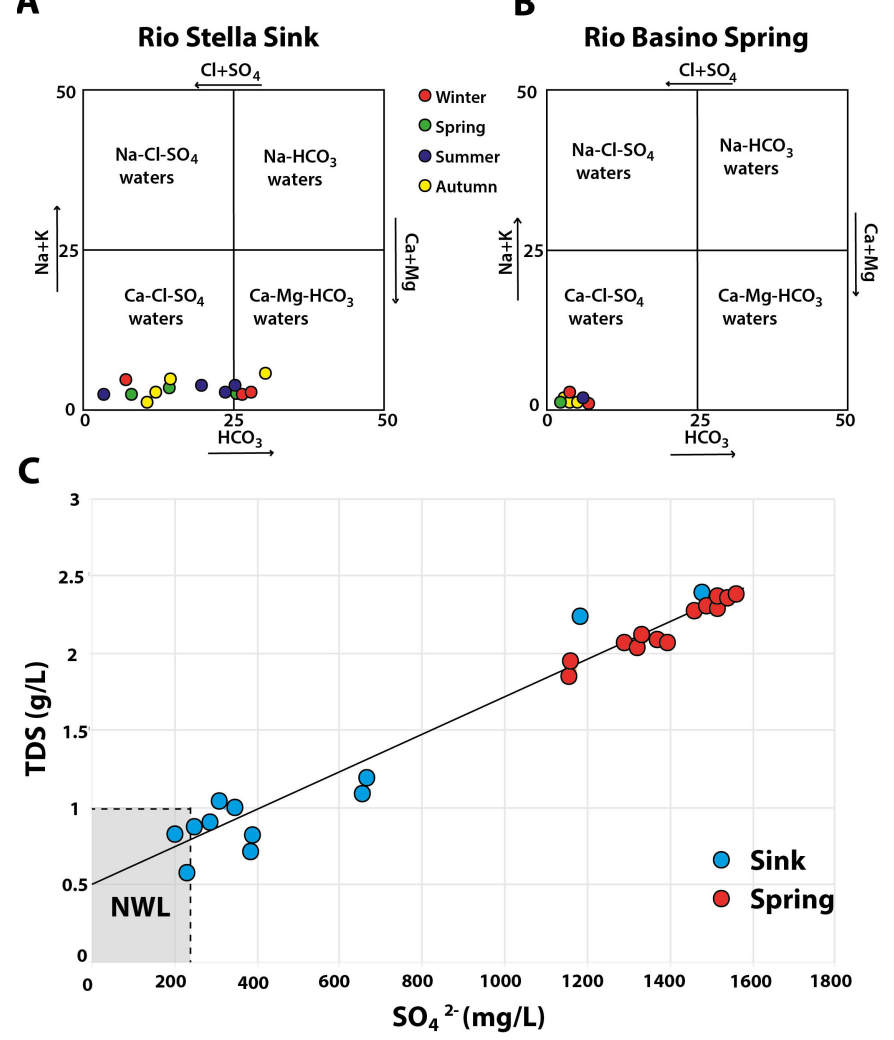

Fig. 6. A) Chemistry of the waters at Rio Stella (sink) and B) Rio Basino (spring) sampling sites. Ludwig-Langelier diagrams show the distribution of waters coming from sink and spring during the four seasons. Waters coming from the sink are more variable than spring waters. C) The diagram shows a clear distribution of sink-spring waters. Almost all the waters exceed the natural water limits (NWL) of $250 \mathrm{mg} / \mathrm{L}$ of $\mathrm{SO}_{4}{ }^{2-}$ and $1.0 \mathrm{~g} / \mathrm{L}$ of TDS (Total Dissolved Solids) fixed by the Council of the European Community (CEC, 1993). The concentration of TDS and $\mathrm{SO}_{4}{ }^{2-}$ are well correlated.

processes. All these data clearly indicate this system to belong to the "dominant conduit drainage" model.

Figure 6A-B shows two Ludwig-Langelier diagrams that represent, respectively, Rio Stella sink (Fig. 6A) and Rio Basino spring (Fig. 6B) during the four seasons. The samples from the sink are quite scattered (from the $\mathrm{Ca}-\mathrm{Mg}-\mathrm{HCO}_{3}$ to $\mathrm{Ca}-\mathrm{Cl}-\mathrm{SO}_{4}$ waters), while the ones from the spring are well-clustered in the Ca$\mathrm{Cl}-\mathrm{SO}_{4}$ waters. In Figure $6 \mathrm{C}$ it is possible to see that waters increase the concentration of $\mathrm{SO}_{4}{ }^{2-}$ and TDS
(Total Dissolved Solids) during the flow from Rio Stella (sink) to Rio Basino (spring).

\section{The Moncalvo aquifer}

Moncalvo, and also Calliano (described below) quarries, are located in the Monferrato area, and both exploit the gypsum rocks through underground excavations (Fig. 7).

At Moncalvo the gypsum sequence is relatively compact with an underground water circulation mainly organized along two independent karst networks, characterized by a relatively different chemical fingerprint. Both surficial waters and rising fluids follow a set of fractures in the host rock (aquitard) and recharge these karst circuits. A series of piezometers installed in the nearby quarry have intercepted these feeding fissures and fractures (Fig. 8). Such piezometers monitored continuously water levels and showed their changes through time are significantly different from those measured in the cave conduits. Piezometers S31, S30, and SN2 have their piezometric level at around 215, 205 , and $180 \mathrm{~m}$ asl respectively, whereas the water level in the Moncalvo cave stays around $135 \mathrm{~m}$ asl (Fig. 9). Piezometer S4, that reached the intensely karstified limestone bed at the bottom of the evaporite sequence, registers the same water level as the intercepted cave system (i.e., around $135 \mathrm{~m}$ asl). Piezometer SVB31, on the other hand, intercepted a still unexplored second cave system, and the water level, instead of being at the same altitude as the known cave, rose to $157 \mathrm{~m}$ asl $(22 \mathrm{~m}$ higher than in the explored Moncalvo Cave).

The main karst network thus appears to be composed of a series of apparently independent wide phreatic water-filled galleries. Originally, the underground quarry levels that developed also below the water level measured in the karst conduits were completely dry and did not evidence any water inflow (Fig. 10A). Only in 2005 one of these underground excavations, incidentally, intercepted one of these phreatic cave passages causing an inrush of $60,000 \mathrm{~m}^{3}$ of water mixed with muds causing the complete flooding of the lower quarry tunnels (Bonetto et al., 2008; Vigna et al., 2009, 2010b).

The speleological exploration of these caves after their dewatering has allowed surveying of 850 meters of cave passages characterized by typical phreatic morphologies (Fig. 10B). A series of small phreatic conduits recharged this karst system from below (hypogene gypsum cave, Banzato et al., 2017) and a gauge has monitored the flow rate of this recharge. These systems, before the quarrying in the area, probably discharged along the valley floors, where the gypsum beds were intercepted by the river network. After the inrush, in 2010, a set of boreholes has been drilled at a lower elevation to allow pumping the water out and thus lowering the local water level. The level of the water, however, continuously monitored by the S4 piezometer at the base of the evaporite sequence, is rather stable with only slight variations in response to the most significant rainfall episodes (Fig. 9). The flow rate changes, measured since 2006, vary 


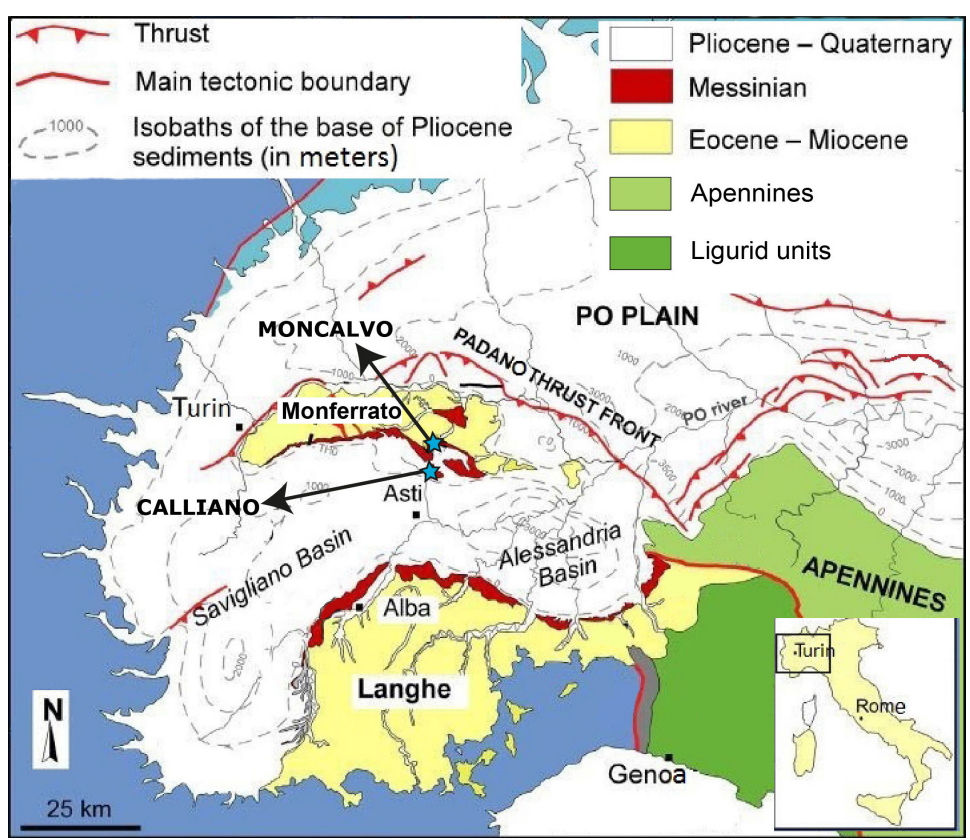

Fig. 7. Simplified geological sketch map showing the gypsum areas in Piedmont (in red) and the two studied areas (Moncalvo and Calliano) using two light blue stars. Modified from Dela Pierre et al. (2011).

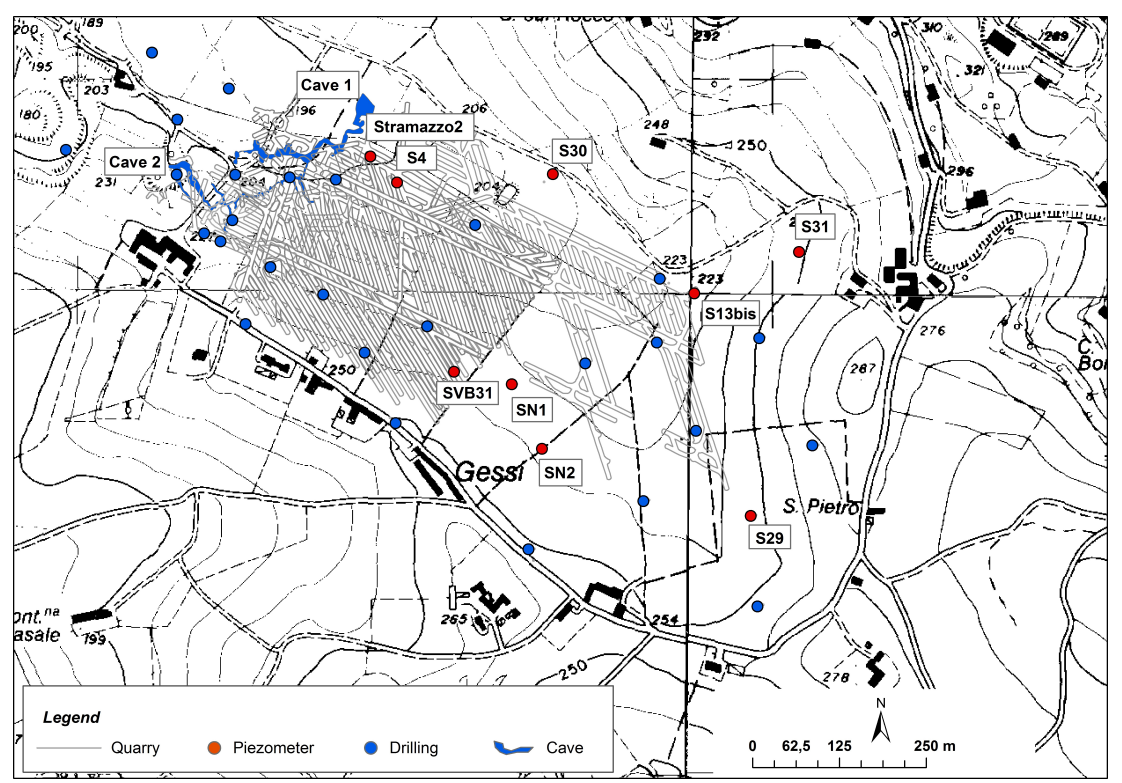

Fig. 8. Monitoring points of the water levels (dots), the underground gypsum quarry development, and the two discovered caves. S4 piezometer reached the limestone bed at the base of the evaporite sequence and water level was at $135 \mathrm{~m}$ asl. SVB31 in the center of the map is the piezometer that intercepted the second unexplored cave system, with water level $22 \mathrm{~m}$ higher than in the Moncalvo caves and S4.

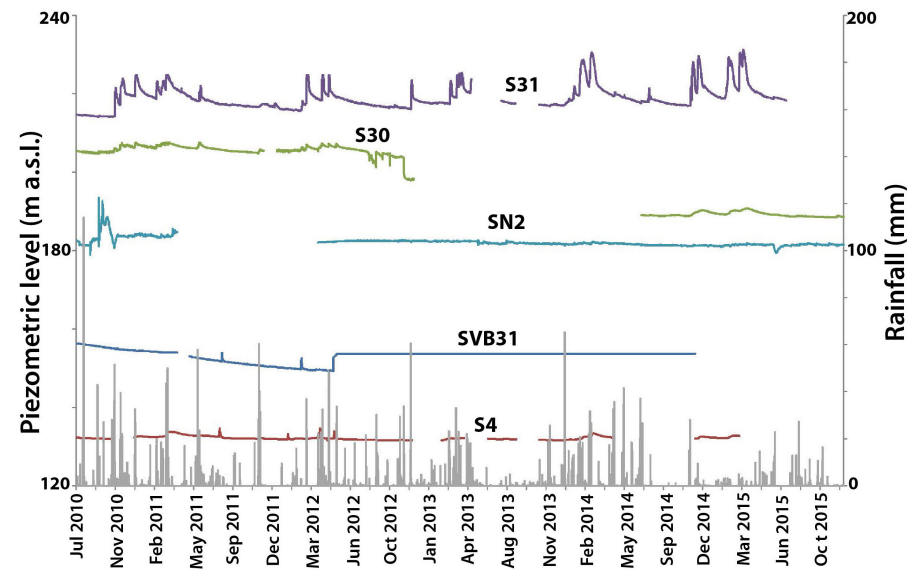

Fig. 9. Rainfall, water levels in the piezometers S30, S31, and SN2 and in the karst network (SVB 31 and S4) at Moncalvo. 


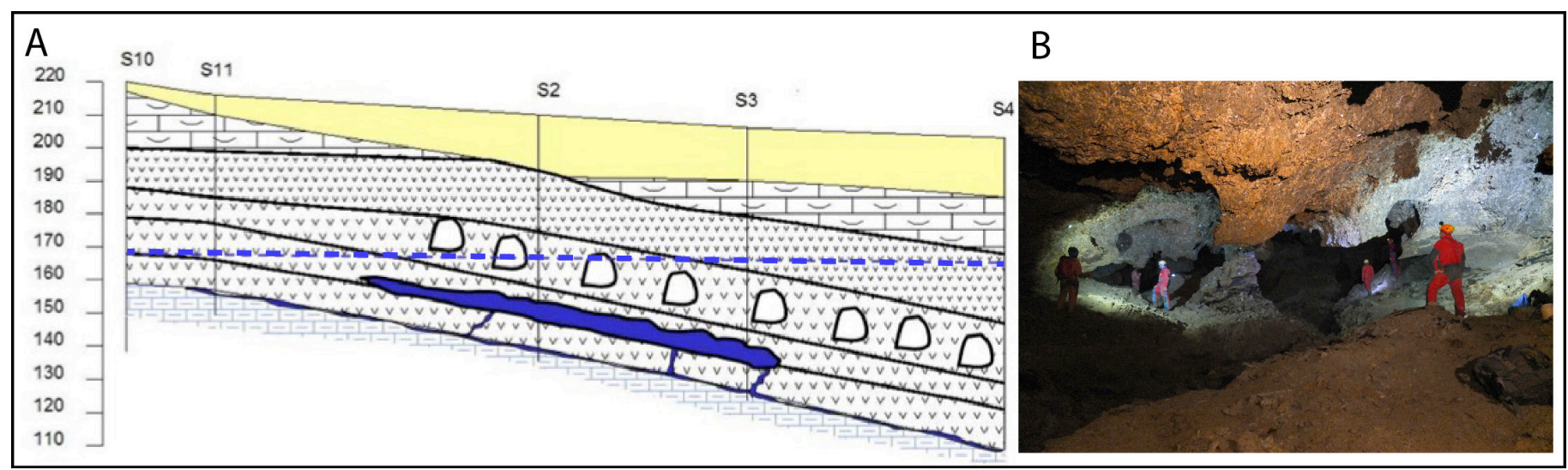

Fig. 10. A) Schematic profile of the Moncalvo area based on drillholes. The three macrocrystalline and the upper microcrystalline gypsum beds are shown. The formation unconformably covering the upper microcrystalline gypsum bed is the "Lago-Mare" sequence, whereas the yellow covering sequences are the post-evaporitic sediments. The blue colored part is the Moncalvo cave system recharged mainly from below (hypogene gypsum cave), and the blue dashed horizontal line represents the water table before the cave was intercepted by the underground quarry in 2005 . The white voids in the gypsum sequence (shown with "v" filling) are underground quarry tunnels; B) The wide phreatic passages in the Moncalvo cave system.

between 6 and $13 \mathrm{~L} / \mathrm{s}$, and show slight variations not correlated significantly with the local rainfall (Fig. 11A). Also electric conductivity (EC) and temperature (T) of the waters vary slightly, without being correlated with the flow rate and the rainfall events (Fig. 11B-C).

During 2009, the second karst system has been intercepted by a series of horizontal exploration drillholes and a vertical borehole (SVB31), in the southeastern sector of the underground gypsum quarry (Fig. 8). These drillholes have entered a karst conduit filled with water, and the water level in SVB31 was approximately $22 \mathrm{~m}$ higher than the level measured in the earlier discovered cave. Until now the operations to drain this new cave have not yet started, but they will allow the exploration of this karst void in the near future. The Moncalvo Aquifer can be defined as a system with "interconnected conduit drainage".

\section{The Calliano aquifer}

The gypsum quarry of Calliano, although only around $5 \mathrm{~km}$ away from Moncalvo, shows a completely different hydrogeological situation. The stratigraphical characteristics of this area see gypsum beds sandwiched between low permeability sediments (aquitards). The gypsum beds, however, are characterized by a much more intense fracturation and contain numerous small karst conduits with diameters less than $20 \mathrm{~cm}$ (Fig. 12A-B). The gypsum aquifer in this area recharged a spring with a flow rate close to $70 \mathrm{~L} / \mathrm{s}$.

During 2009, some underground quarry excavation works, located several tens of meters below the ground surface, started close to this spring. To allow the quarrying of the gypsum rocks below the local groundwater level a set of drainage galleries has been realized up to a depth of $60 \mathrm{~m}$ below the spring altitude (Fig. 13A). These galleries have intercepted a large quantity of small karst conduits and water-bearing fractures showing there was a clear water circulation many meters below the external surface. These subterranean waters are collected

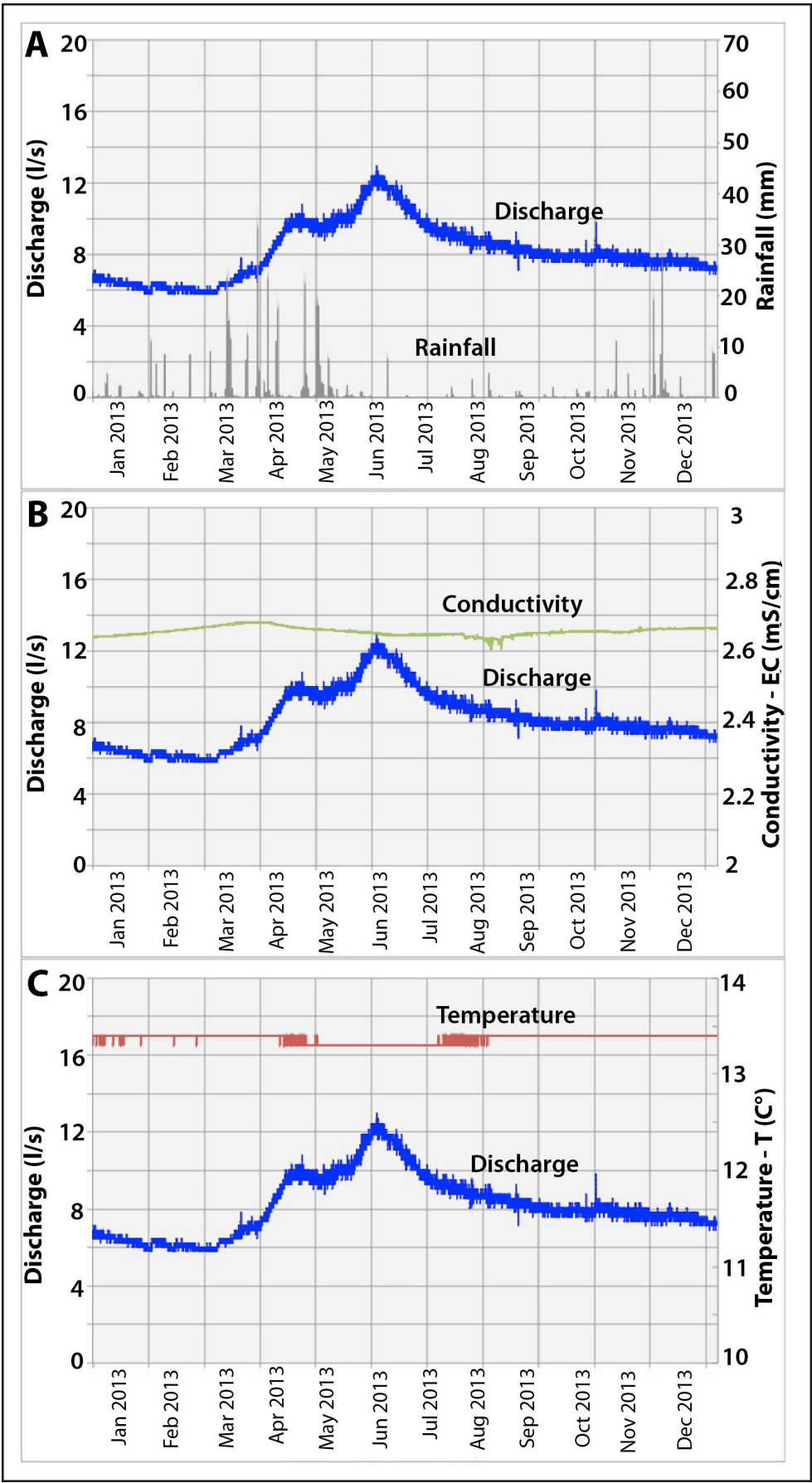

Fig. 11. A) Rainfall and flow rate; B) Flow rate and Electric Conductivity (EC); and C) Flow rate and Temperature ( $T$ ) measured in Moncalvo waters during 2013. 
in a series of underground tanks and pumped to the surface (Fig. 13B).

From 2010 to 2015 the water abstraction quantity has passed from 100 to $70 \mathrm{~L} / \mathrm{s}$ and allowed lowering of the local water level by a couple of tens of meters, causing the spring to dry out completely. A series of piezometers has been installed in the hilly area around the quarry to monitor the water level changes and the underground water flow (Fig. 14). These piezometers, some reaching more than 100 meters of depth below the ground surface, have allowed definition of the geometry of the potentiometric surface, showing a striking similarity with that of porous aquifers, in continuity and more or less following the surface topography (Fig. 15). The water level changes measured in these piezometers and caused by the pumping in the drainage galleries show a very similar behavior (Fig. 16). These observations are in agreement with a model that is based on an extensively fractured and karstified aquifer with very good interconnection among fractures and karst conduits. The sudden lowering of the water level measured in piezometer S20 is due to its interception by an underground quarry tunnel. Calliano is a classical example of a "dispersive karst circulation system".

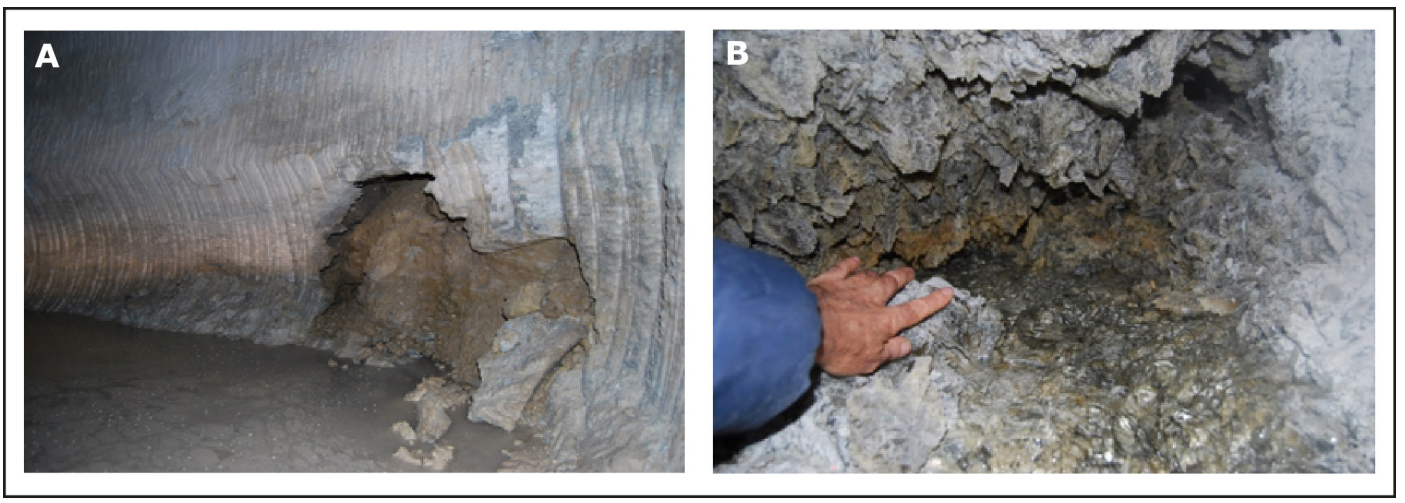

Fig. 12. Calliano underground quarry. A) A water-bearing fracture intercepted by the quarry tunnel; B) A small phreatic karst conduit along the walls of a quarry tunnel.

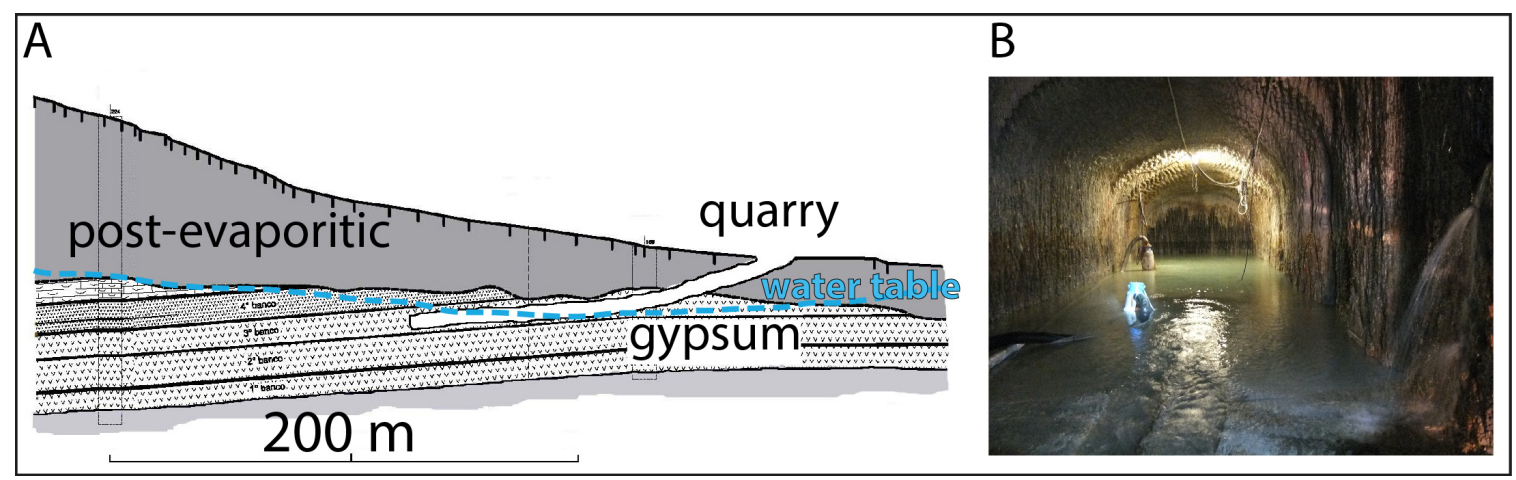

Fig. 13. A) Schematic cross-section of the Calliano Quarry; B) A drainage tunnel in the Calliano Quarry: some inflowing waters can be seen in the foreground, while the collection system and the pumping devices are in the background.

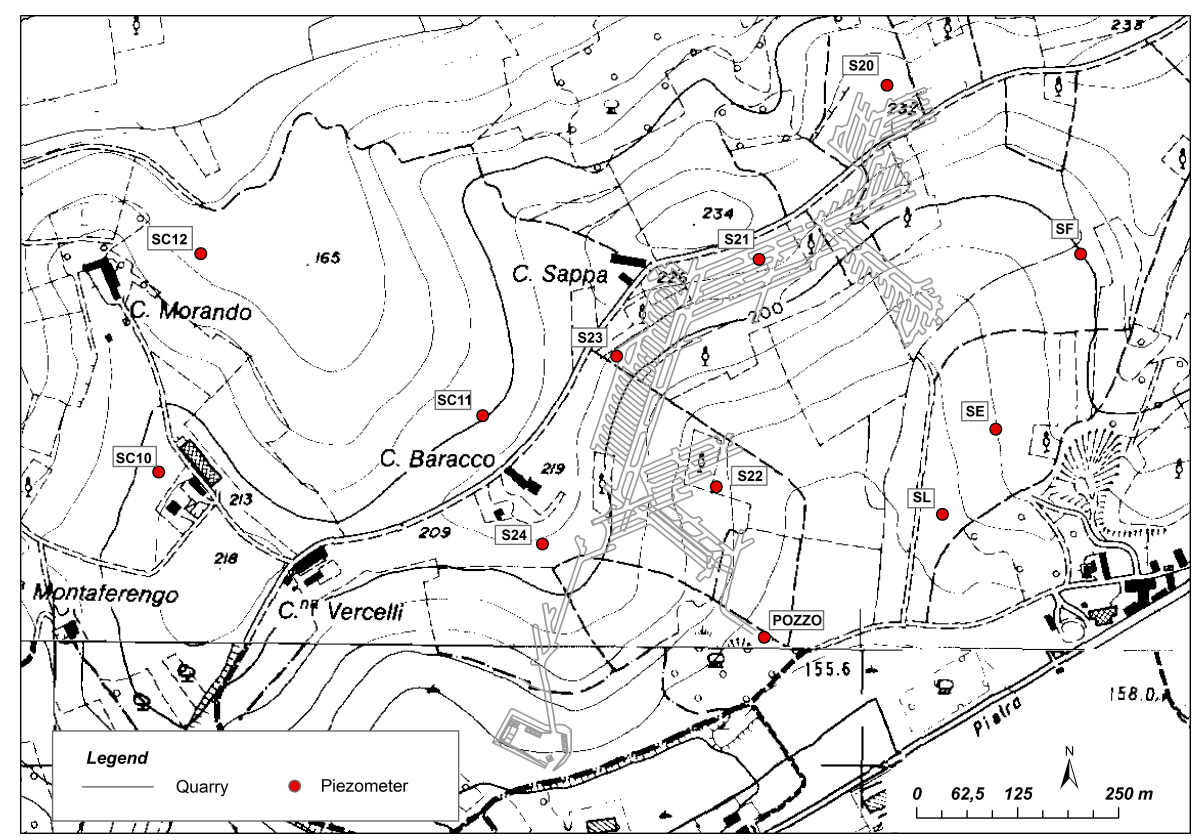

Fig. 14. Monitoring sites of water level in the underground quarry of Calliano. 


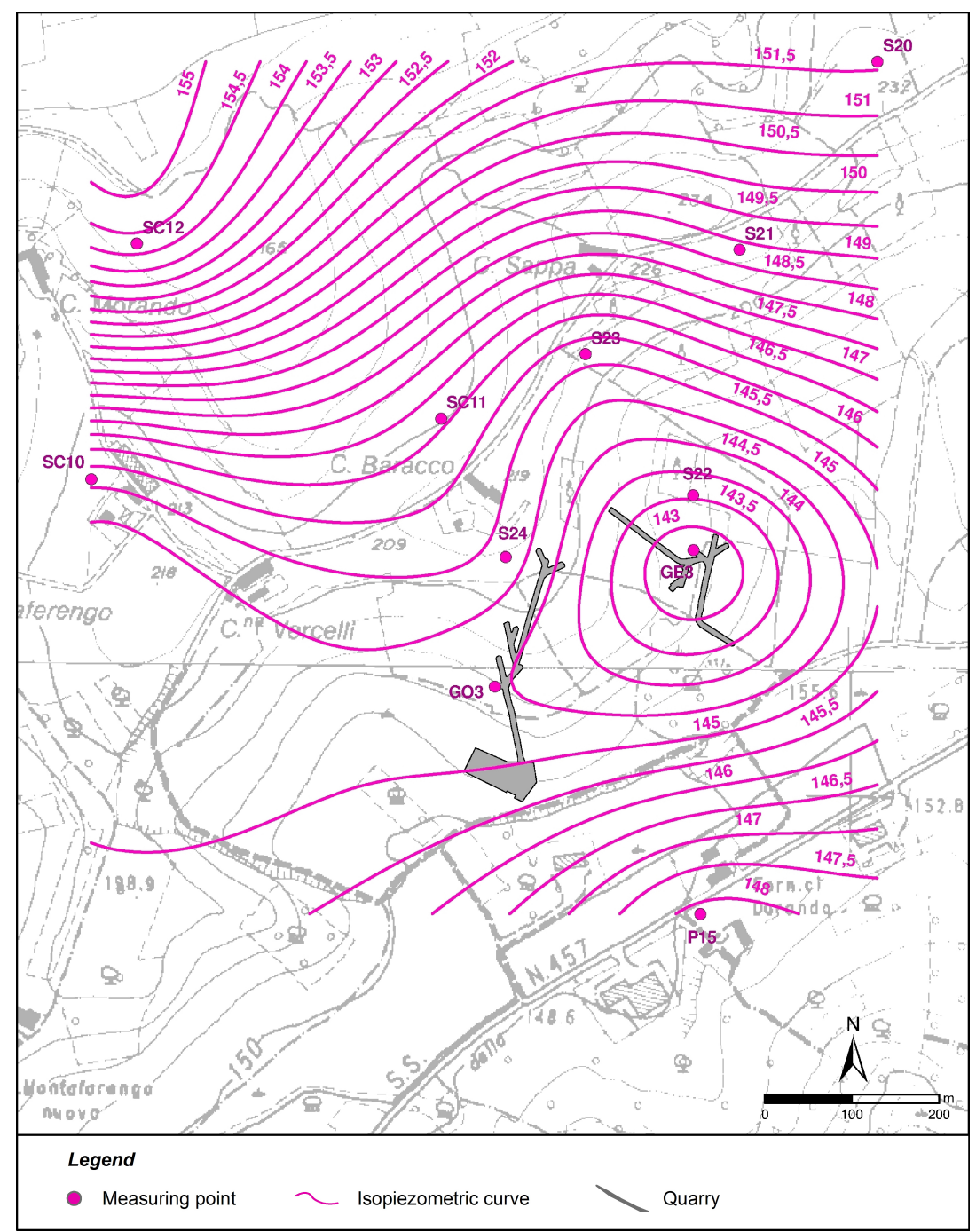

Fig. 15. Piezometric surface as reconstructed based on the piezometers installed near the Calliano Quarry.

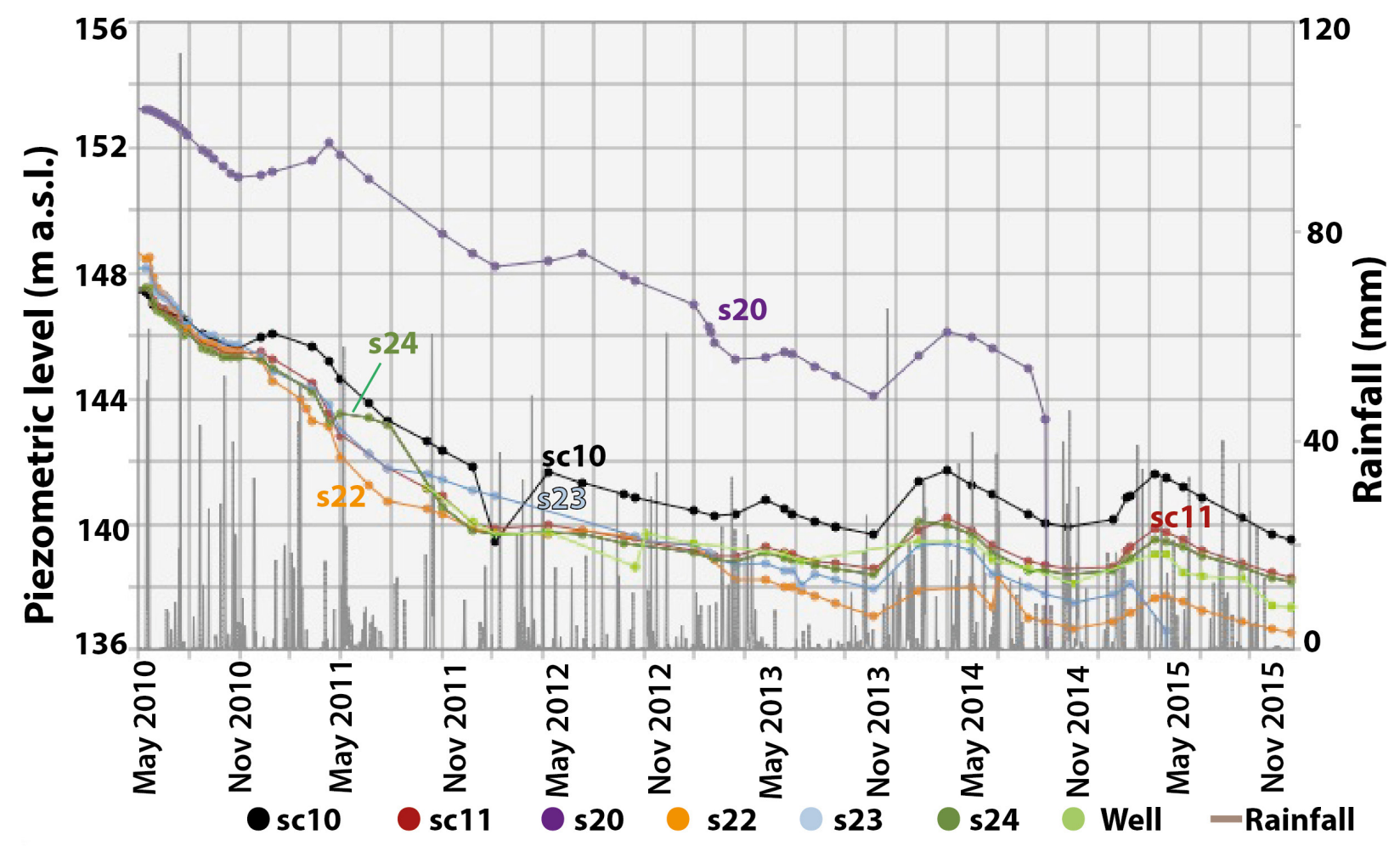

Fig.16. Lowering of the water levels in several boreholes close to the quarry following the pumping at Calliano. 


\section{Geochemistry}

Geochemical analyses have been carried out in all these described systems (Fig. 17). In the Schoeller diagram are reported six sampling sites (E9, VE5, F2, F3, F4, and VBB). E9 represents Rio Basino spring, VE5 is a sampling site in Calliano cave system and F2F3-F4-VBB are located in Moncalvo cave system. Each sampling site has been investigated both in maximum $(\mathrm{M})$ and in minimum $(\mathrm{m})$ mineralization state.

It is well-known that most waters that cross the gypsum rocks get saturated in gypsum almost immediately (Klimchouk, 1996). Their chemistry is of the $\mathrm{Ca}-\mathrm{SO}_{4}$ type $\left(\mathrm{Ca}^{2+}>\mathrm{Mg}^{2+}>\mathrm{Na}^{+}\right.$and $\mathrm{SO}_{4}{ }^{2-}$ $>\mathrm{HCO}_{3}^{-}>\mathrm{Cl}^{-}$). In the karst systems like Moncalvo and Calliano the chemical variations are rather subdued. These variations mainly concern $\mathrm{Mg}, \mathrm{Na}, \mathrm{K}$, $\mathrm{Cl}$, and $\mathrm{NO}_{3}$, whereas in karst systems such as Rio Stella-Basino also $\mathrm{Ca}, \mathrm{SO}_{4}$, and $\mathrm{HCO}_{3}$ values show significant variations. Total mineralization is greater in the Moncalvo and Calliano systems respect to Rio Stella-Basino system, due to the longer water-rock interaction in the first two. At Moncalvo two different waters have been identified: a calcic-sulfate one (samples F2, F3, and F4) with an important amount of nitrates and a positive redox potential (Eh), similar to the waters encountered at Calliano (VE5); and a second type (VBB) with a main calcic-sulfate facies and a secondary chloride-alcaline facies, with low levels of nitrates and a negative redox potential (Eh). The last waters (VBB) are related to a deeper circulation with rather long residence times, leading to the negative Eh, reduction of nitrates in ammonium, and a major content in calcium and sulfates, related to the higher presence of dissolved sodium-chloride that increases the solubility of the sulfates.

\section{CONCLUSIONS}

The hydrogeological data collected in the gypsum aquifers of Emilia-Romagna and in the hilly area around Monferrato, in Piedmont region, have allowed the definition of three very different conceptual underground drainage models in gypsum rocks, similar to those generally known from carbonate aquifers (Vigna \& Banzato, 2015) (Fig. 18). Whereas the first model (systems with dominant conduit drainage) appears to be the most common, characterizing most of the known Italian gypsum aquifers, the other two models (systems with interconnected conduit drainage and systems with dispersive circulation) have been recognized thanks to the presence of underground gypsum quarries that have intercepted these aquifers, and allowed their monitoring by means of piezometers and direct underground observations.

In the extensive gypsum outcrops of Emilia-Romagna the groundwater circulation is mainly developed along a set of well-developed vadose karst conduits and secondary tributaries allowing water to flow rapidly from the recharge areas to the springs. The landscape is characterized by gypsum ridges standing out on the rest of the lithologies, creating orographic barriers to the waters flowing at the surface, leading to the formation of sinks and related subterranean cave systems. Generally the phreatic zone is scarcely developed if not completely absent, and the recharge from the surrounding gypsum rock is very low. Flow rates are very variable, depending on rainfall, and flow velocities can be very fast, up to $500 \mathrm{~m} / \mathrm{h}$. The geochemistry and temperature of the waters is very variable, with a lowering of EC (Electrical Conductivity) and often also of $\mathrm{T}$ (Temperature) after important

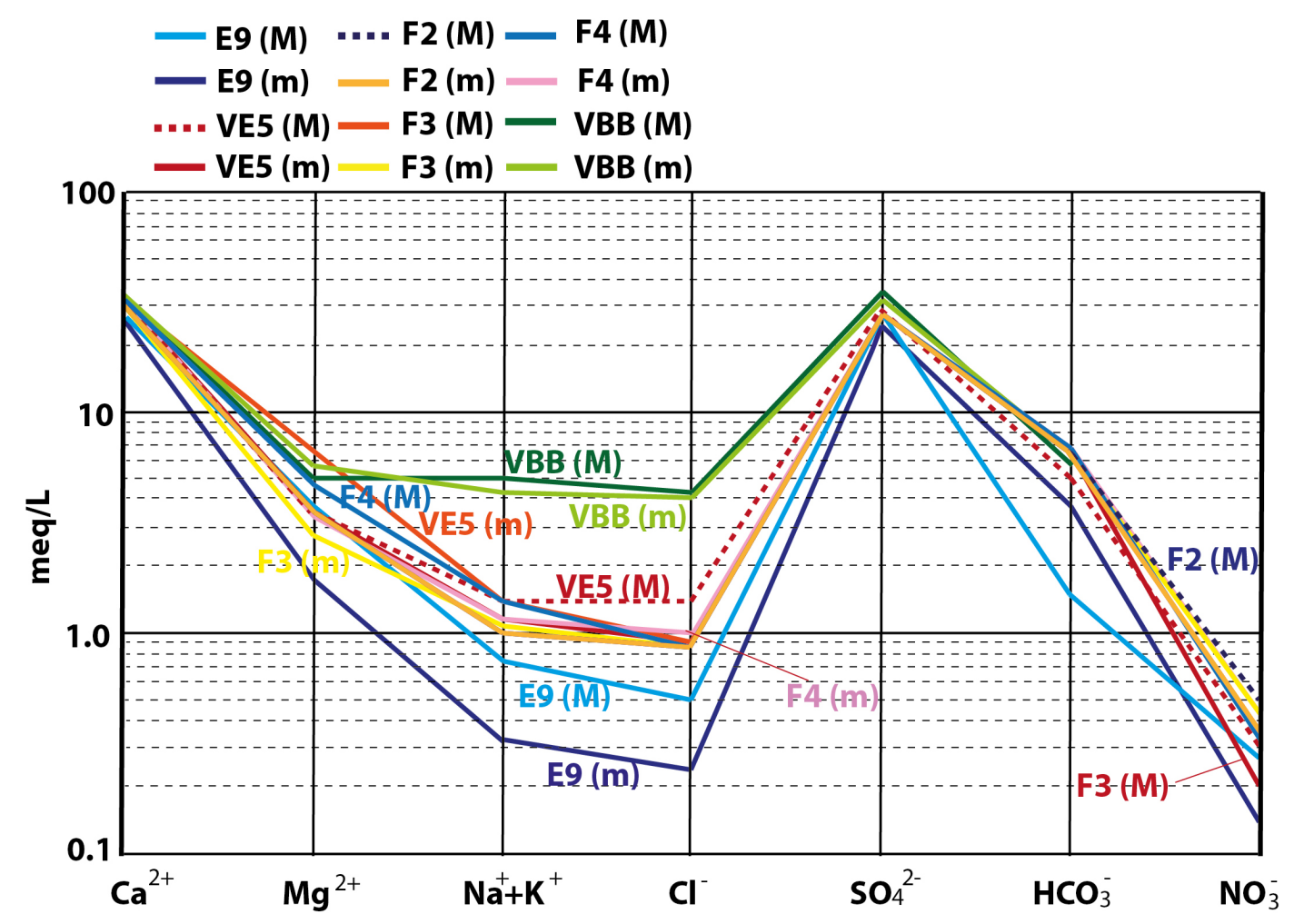

Fig. 17. Schoeller diagram representing six sampling sites of the three cave systems: Rio Basino spring (E9); Calliano cave system (VE5); surficial waters from Moncalvo (F2-F3-F4) and deep waters from Moncalvo cave system (VBB). M represents the maximum mineralization state, whereas $m$ the minimum one of the same sampling site. 
infiltration events (and thus increase in flow rate) due to the fact that infiltrating waters rapidly substitute the waters resident in the system. These systems can be classified as systems with dominant conduit drainage (Fig. 18A).

In the areas where the evaporite rocks are covered by important low permeability sediments (typical of Piedmont region) the hydrogeological situation is completely different, very much depending on the fracturing of the host rock. The landscape in these areas is hilly with no evident gypsum outcrops, and no sinking streams. Near the town of Moncalvo d'Asti the gypsum rock is very compact, but in the presence of thin marly-clayey interlayers separating the different gypsum beds a well-developed karst aquifer has developed, in which water flows at rates around $10 \mathrm{~L} / \mathrm{s}$. The interception of these karst voids in the quarry tunnels (several tens of meters below the surface) has unveiled large natural caves with typical phreatic morphologies. In adjacent gypsum compartments, boreholes have intercepted similar water-filled karst voids, with water levels that are at

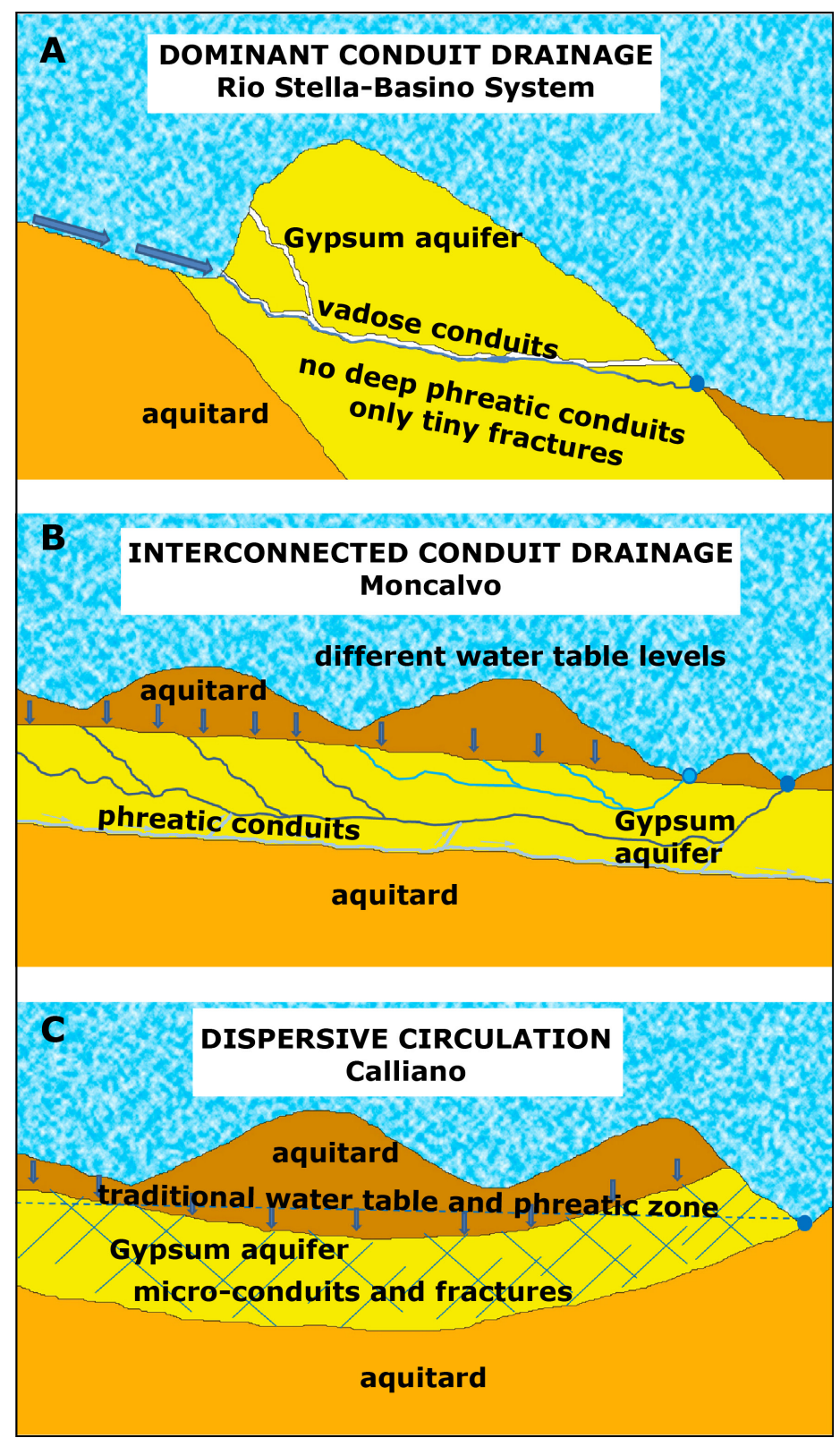

Fig. 18. Conceptual models showing the three different modes of groundwater circulation in gypsum aquifers. different altitudes. The genesis of these circuits can be put in relation with both slowly infiltrating waters from the surrounding aquitards and rising (hypogene) flows as shown by the very different chemistry of these fluids with respect to the surfacial waters (Vigna et al., 2010b). The flow rate variations and the chemistry of these waters evidences that most of the recharge originally comes from the surface (with long routes), with rather subdued variations in flow rate, related to the recharge of the above lying aquitards. This aquifer can be classified as a "system with interconnected conduit drainage" characterized by a rather developed phreatic zone with large phreatic conduits (Fig. 18B).

In the area close to the town of Calliano (Asti province) a gypsum aquifer originally fed a spring with a rather constant flow rate close to $70 \mathrm{~L} / \mathrm{s}$. A set of boreholes has allowed definition of the water table that demonstrates the system to be classifiable as a "system with dispersive circulation" (Fig. 18C). The gypsum rock is intensely fractured, has a rather low general permeability, and does not show preferential drainage paths or karst conduits. Monitoring boreholes have intercepted many small karst conduits and water-containing fractures up to a depth of over $60 \mathrm{~m}$ below the spring, demonstrating a subterranean flow well below the level of the potentiometric level. Geochemistry is rather constant in time, and flow rates show only slight variations not directly correlated to infiltration events. In general, a water table level is created, similar to a classical piezometric surface in porous aquifers.

These three conceptual models of underground water circulation in the evaporite karsts are very similar to the models explaining the flow in carbonate aquifers (Vigna, 2007, Vigna \& Banzato, 2015). The gypsum aquifers most vulnerable to pollution are those with a dominant drainage system, where pollutants can travel very far and fast without undergoing a significant modification from their injection points to the springs. The system less vulnerable to pollution is the one with dispersive circulation, behaving in a similar way as a porous aquifer (with a higher filtration power), albeit with more rapid responses.

\section{ACKNOWLEDGEMENTS}

Cinzia Banzato helped during the many years of monitoring in the Moncalvo and Calliano quarries and with the elaboration of the graphics. The work in Emilia-Romagna has been carried out in the framework of the Project LIFE+ 08 NAT/ IT/00369 "GYPSUM" (2010-2014) coordinated by the Regional Park of "Gessi Bolognesi e dei Calanchi dell'Abbadessa". Many thanks to all the cavers of the Federazione Speleologica Regionale dell'Emilia-Romagna that helped sampling waters and setting up monitoring equipment, in particular, Baldo Sansavini, Stefano Bergianti and Claudio Dalmonte. The work of three anonymous reviewers has given us the opportunity of improving our manuscript considerably. 


\section{REFERENCES}

Aghdam J.A., Zare M., Capaccioni B., Raeisi E. \& Forti P., 2012 - The Karun River waters in the Ambal ridge region (Zagros mountain Range, southwestern Iran): mixing calculation and hydrogeological implications. Carbonates and Evaporites, 27: 251-267.

https://doi.org/10.1007/s13146-012-0083-8

Andreo B., Gil-Márquez J.M., Mudarra M., Linares L. \& Carrasco F., 2016 - Hypothesis on the hydrogeological context of wetland areas and springs related to evaporitic karst aquifers (Málaga, Córdoba and Jaén provinces, Southern Spain). Environmental Earth Sciences, 75 (9): 1-19.

https://doi.org/10.1007/s12665-016-5545-1

Bakalowicz M., 2015 - Karst and karst groundwater resources in the Mediterranean. Environmental Earth Sciences, 74 (1): 5-14.

https://doi.org/10.1007/s12665-015-4239-4

Banzato C., Vigna B., Fiorucci A. \& De Waele J., 2017 - Hypogene gypsum caves in Piedmont (N-Italy). In: Klimchouk A.B., Palmer A.N., De Waele J., Auler A. \& Audra P. (Eds.), Hypogene karst regions and caves of the world. Cave and Karst Systems of the World book series, Springer.

https://doi.org/10.1007/978-3-319-53348-3_13

Benavente Herrera J. \& Carrasco Cantos F., 1986 Influence of evaporite karst in the streamwater quality of Guadalhorce River (Andalucia, Spain). Le Grotte d'Italia, 4 (12): 39-48.

Bergianti S., Capaccioni B., Dalmonte C., De Waele J., Formella W., Gentilini A., Panzeri R., Rossetti S. \& Sansavini G., 2013 - Progetto Life + 08 NAT/IT/000369 "GYPSUM". Primi risultati sulle analisi chimiche delle acque nei gessi dell'Emilia Romagna. In: Cucchi F. \& Guidi P. (Eds.), Atti del XXI Congresso Nazionale di Speleologia "Diffusione delle conoscenze", Trieste 2-5 giugno 2011: 296-301.

Bonetto S., Fiorucci A., Fornaro M. \& Vigna B., 2008 Subsidence hazard connected to quarrying activities in karst area: the case of the Moncalvo sinkhole event (Piedmont, NW Italy). Estonian Journal of Earth Sciences, Estonian Journal of Earth Sciences, 57: 125-134.

https://doi.org/10.3176/earth.2008.3.01

Calaforra J.M. \& Pulido-Bosch A., 1993 - The hydrogeochemistry and morphology of the Triassic gypsum in the Salinas-Fuente Camacho area (Granada). In: Pulido-Bosch A. (Ed.), Some Spanish karstic aquifers. Maracena (Granada), TG Arte: 67-83.

Calaforra J.M. \& Pulido-Bosch A., 1999 - Gypsum karst features as evidence of diapiric processes in the Betic Cordillera, Southern Spain. Geomorphology, 29: 251-264.

https://doi.org/10.1016/S0169-555X(99)00019-7

Calaforra J.M., Pulido-Bosch A. \& Lopez-Chicano M., 2002 - Gypsum karst in the Betic Cordillera (South Spain). Carbonates and Evaporites, 17 (2): 134-141. https://doi.org/10.1007/BF03176479

Casali R., 1972 - Idrologia ipogea della zona compresa fra i torrenti Zena ed Idice in località Farneto (S. Lazzaro in Savena Bologna). Rassegna Speleologica Italiana, Memoria 10: 148-152.

Chiesi M. \& Forti P. (Eds.), 2009 - Il Progetto Trias: studi e ricerche sulle evaporiti triassiche dell'alta valle di Secchia e sull'acquifero carsico di Poiano (Reggio Emilia). Memorie dell'Istituto Italiano di Speleologia, 2 (22): 1-164.
Chiesi M., Forti P. \& De Waele J., 2010 - Origin and evolution of a salty gypsum/anhydrite karst spring: the case of Poiano (Northern Apennines, Italy). Hydrogeology Journal, 18: 1111-1124.

https://doi.org/10.1007/s10040-010-0576-2

Columbu A., De Waele J., Drysdale R., Woodhead J., Hellstrom J. \& Forti P., 2015 - Gypsum caves as indicators of climate-driven river incision and aggradation in a rapidly uplifting region. Geology, 43 (6): 539-542. https://doi.org/10.1130/G36595.1

Columbu A., Chiarini V., De Waele J., Drysdale R., Woodhead, J., Hellstrom J. \& Forti P., 2017 - Late quaternary speleogenesis and landscape evolution in the northern Apennine evaporite areas. Earth Surface Processes and Landforms (in press).

https://doi.org/10.1002/esp.4099

Council of the European Communities (CEC) 1993. Commission proposal for a Council Directive on the ecological quality of surface waters. COM (93) 680 of 10 August 1994.

D’Angeli I. M., Serrazanetti D. I., Montanari C., Vannini L., Gardini F., \& De Waele J., 2017 - Geochemistry and microbial diversity of cave waters in the gypsum karst aquifers of Emilia Romagna region, Italy. Science of the Total Environment, 598: 538-552.

https://doi.org/10.1016/j.scitotenv.2017.03.270

Dela Pierre F., Clari P., Cavagna S. \& Bicchi E., 2002 - The Parona chaotic complex: a puzzling record of the Messinian (Late Miocene) events in Monferrato (NW Italy). Sedimentary Geology, 152: 289-311. https://doi.org/10.1016/S0037-0738(02)00097-0

Dela Pierre F., Festa A. \& Irace A., 2007 - Interaction of tectonic, sedimentary and diapiric processes in the origin of chaotic sediments: an example from the Messinian of Torino Hill (Tertiary Piedmont Basin, northwestern Italy). Geological Society of America Bulletin, 119: 1107-1119. https://doi.org/10.1130/B26072.1

Dela Pierre F., Bernardi E., Cavagna S., Clari P., Gennari R., Irace A., Lozar F., Lugli S., Manzi V., Natalicchio M., Roveri M. \& Violanti D., 2011 - The record of the Messinian salinity crisis in the Tertiary Piedmont Basin (NW Italy): The Alba section revisited. Palaeogeography, Palaeoclimatology, Palaeoecology, 310 (3): 238-255. https://doi.org/10.1016/j.palaeo.2011.07.017

Dela Pierre F., Clari P., Bernardi E., Natalicchio M., Costa E., Cavagna S., Lozar F., Lugli S., Manzi V., Roveri M. \& Violanti D., 2012 - Messinian carbonaterich beds of the Tertiary Piedmont Basin (NW Italy): microbially-mediated products straddling the onset of the salinity crisis. Palaeogeography, Palaeoclimatology, Palaeoecology, 344: 78-93.

https://doi.org/10.1016/j.palaeo.2012.05.022

De Waele J., Piccini L., Columbu A., Madonia G., Vattano M., Calligaris C., D’Angeli I. M., Parise M., Chiesi M., Sivelli M., Vigna B., Zini L., Chiarini V., Sauro F., Drysdale R. \& Forti P., 2017 - Evaporite karst in Italy: a review. International Journal of Speleology, 46 (2): 137-168.

https://doi.org/10.5038/1827-806X.46.2.2107

Ford D.C. \& Williams P.W., 2007 - Karst hydrogeology and geomorphology. Chichester, John Wiley \& Sons Ltd., $562 \mathrm{p}$. https://doi.org/10.1002/9781118684986

Forti P. \& Francavilla F., 1990 - Gli acquiferi carsici dell'Emilia-Romagna: conoscenze attuali e problemi di salvaguardia. Acta Naturalia dell'Ateneo di Parma, 26 (1-2): 69-80. 
Forti P. \& Lucci P. (Eds.), 2010 - Il Progetto Stella-Basino. Studio multidisciplinare di un sistema carsico nella Vena del Gesso Romagnola. Memorie dell'Istituto Italiano di Speleologia, II (14): 260 p.

Forti P., Francavilla F., Prata E., Rabbi E., Veneri P. \& Finotelli F., 1985 - Evoluzione idrogeologica dei sistemi carsici dell'Emilia-Romagna: 1- Problematica generale; 2- Il complesso Spipola - Acqua Fredda. Bologna, Regione Emilia Romagna: 1-60.

Forti P., Alessandrini A., Bertolani Marchetti D., Bertolani M., Borghi E., \& Canossini D., 1988 - L'area carsica dell'alta Val di Secchia, studio interdisciplinare dei caratteri ambientali. Reggio Emilia, Studi e Documentazioni, 42: 1-303.

Forti P., Francavilla F., Prata E., Rabbi E. \& Griffoni A., 1989 - Evoluzione idrogeologica dei sistemi carsici dell'Emilia-Romagna: il complesso Rio Stella-Rio Basino (Riolo Terme, Italia). Atti XV Congresso Nazionale di Speleologia, Castellana Grotte: 349-368.

Ghibaudo G., Clari P. \& Perello M., 1985 - Litostratigrafia, sedimentologia ed evoluzione tettonico-sedimentaria dei depositi miocenici del margine sud-orientale del Bacino Terziario ligure-piemontese (Valli Borbera, Scrivia e Lemme). Bollettino della Societa Geologica Italiana, 104: 349-397.

Gil-Márquez J.M., Barberá J.A., Andreo B. \& Mudarra M., 2017 - Hydrological and geochemical processes constraining groundwater salinity in wetland areas related to evaporitic (karst) systems. A case study from Southern Spain. Journal of Hydrology, 544: 358-554. https://doi.org/10.1016/j.jhydrol.2016.11.062

Günay G., 2002 - Gypsum karst, Sivas, Turkey. Environmental Geology, 42: 387-398. https://doi.org/10.1007/s00254-002-0532-0

Kaçaroğlu F., Değirmenci M. \& Cerit O., 2001 - Water quality problems of a gypsiferous watershed: upper Kizilirmak basin, Sivas, Turkey. Water, Air, and Soil Pollution, 128: 161-180.

https://doi.org/10.1023/A:1010333522184

Klimchouk A., 1996. The dissolution and conversion of gypsum and anhydrite. International Journal of Speleology, 25 (3-4): 21-36.

https://doi.org/10.5038/1827-806X.25.3.2

Lucci P. \& Rossi A. (Eds.), 2011 - Speleologia e geositi carsici in Emilia-Romagna. Bologna, Pendragon, 448 p.

Madonia G. \& Forti P., 2003 - Le aree carsiche gessose d'Italia. Italian Institute of Speleology, Bologna, Memorie dell'Istituto Italiano di Speleologia, 2 (14): 1-285.
Pulido-Bosch A. \& Calaforra J.M., 1993 - The gypsum karstic aquifer of Sorbas (Almeria). In: Pulido-Bosch A. (Ed.). Some Spanish karstic aquifers. Maracena (Granada), TG Arte: 225-241.

Raeisi E., Zare M. \& Aghdam J.A., 2013 - Hydrogeology of gypsum formations in Iran. Journal of Cave and Karst Studies, 75 (1): 68-80.

https://doi.org/10.4311/2011ES0234

Sturani C., 1976 - Messinian facies in the Piedmont basin. Memorie della Società Geologica Italiana, 16: 11-25.

Tedeschi L., D’Angeli I.M., Vigna B., Dalmonte C. \& De Waele J., 2015 - Comportamento idrogeologico di alcune risorgenti carsiche nei gessi dell'Emilia-Romagna. In: De Nitto L., Maurano F. \& Parise M. (Eds), Atti del XXII Congresso Nazionale di Speleologia, Pertosa-Auletta (SA), 30/05-02/06/2015. Memorie Istituto Italiano di Speleologia, 2 (29): 399-404.

Vai G.B. \& Martini I.P., 2001 - Anatomy of an orogen: The Apennines and adjacent Mediterranean. Dordrecht, Netherlands, Kluwer Academic Publishers, $631 \mathrm{p}$. https://doi.org/10.1007/978-94-015-9829-3

Vai G.B. \& Ricci Lucchi F., 1977 - Algal crusts, autochthonous and clastic gypsum in a cannibalistic evaporite basin: a case history from the Messinian of Northern Apennines. Sedimentology, 24: 211-244. https://doi.org/10.1111/j.1365-3091.1977.tb00255.x

Vigna B., 2007 - Schematizzazione e funzionamento degli acquiferi in rocce carbonatiche. Memorie dell'Istituto Italiano di Speleologia. 2 (19): 21-26.

Vigna B. \& Banzato C., 2015 - The hydrogeology of highmountain carbonate areas: an example of some Alpine systems in Southern Piedmont (Italy). Environmental Earth Sciences, 74: 267-280. https://doi.org/10.1007/s12665-015-4308-8

Vigna B., Fiorucci A., De Waele J. \& Banzato C., 2009 - Messinian karst in Monferrato gypsum areas (North Italy). In: White W.B. (Ed.), Proceedings of the $15^{\text {th }}$ International Congress of Speleology, Kerville, Texas (USA) July 19-26, Vol. 2: 1003-1009.

Vigna B., Fioraso G., Banzato C. \& De Waele J., 2010a - Evolution of karst in Messinian gypsum (Monferrato, Northern Italy). Geodinamica Acta, 23 (1-3): 29-40. https://doi.org/10.3166/ga.23.29-40

Vigna B., Fiorucci A., Banzato C., Forti P. \& De Waele J., 2010b - Hypogene gypsum karst and sinkhole formation at Moncalvo (Asti, Italy). Zeitschrift für Geomorphologie, 54 (2): 285-306. https://doi.org/10.1127/0372-8854/2010/ $\underline{0054 \text { S2-0015 }}$ 